\title{
When Heredity Met the Bacterium: Quarantines in New York and Danzig, 1898-1921
}

\author{
Gerd Korman
}

\section{Section I.}

Recent careful examinations of American quarantines placed on incoming migrants have found that health officials were potent carries of bigotries rooted in the larger society ${ }^{1}$; but usually historians have not paid sufficient attention to the complex challenges facing quarantine units in action. By examining the work of quarantine health officials dealing with migrating Jews from East Central Europe this analytical narrative seeks to show in detail important structural circumstances within which acts of bigotry manifested themselves between the 1890s and 1920s.

The narrative also has a larger agenda. Connections between public health quarantines and bio-cultural determinisms have long participated in the construction of public enemies. For instance in the 1980s, during the early years of the AIDS panic in the United States, public health officials could take for granted a citizenry that had long trusted in abstract empirical scientific knowledge and, for half a century, in the disease curing power of pharmacology's sulfa drugs and other antibiotics. Even so, in the first moments of panic all sorts of calls for screens and quarantine impacted on public policy discussions in ways reminiscent of the years between the 1890s and 1920s. During those years biological determinisms from the past had remained in the saddle. Even as modern public health programmes were becoming dramatically successful in fighting disease, they remained affected by hierarchies of bio-cultural notions, especially in apprehensions about immigrants as agents of dangerous contagious diseases.

That is one reason why this article focuses on Jews. The other reason derives from the evidence about Jews and disease in the places and times covered by this study. To be sure, there were other quarantines, involving, for example, resident Chinese and Italians; and in the months after the First World War potential incomers from Italy were at least as much an object of concern among American advocates of immigration restriction as were the Jews in Poland. But, in part, because of a typhus epidemic in that war-torn country, the association between disease and bio-cultural assumptions about Jews retained its traditional particularity in Western Europe and in the United States.

During the 1890s, within a Darwinian framework, the young revolution of the germ theory of disease was well under way, but in the public health arena, as in biology and medicine in general, older convictions and practices were still competing with new concepts and bacteriological findings. In Philadelphia quarantine practitioners continued to treat ships from abroad as miasmatic vessels, that is as the primary "source of disease", in comparison to individual passengers as the potential pathogenic agent ${ }^{2}$. Even so, at the century's turning, advocates of the new were demonstrating to their own satisfaction the effectiveness of applied bacteriological knowledge in efforts to control and even stop the spread of a dangerous epidemic: a transformed urban water supply, more or less free of disease-causing germs, was one of their most powerful defences against deadly pathogens.

By the era of the First World War, victory was in the hands of bacteriologists and their diagnostic tools. Unfortunately, the new laboratory scientists, let alone the medical establishment, had failed to find reliable cures for the specific life-threatening contagious bacilli such as cholera, tuberculosis, or typhus now being observed under the microscope and diagnosed in the person

\footnotetext{
1 Alan M. Kraut, Silent Travelers: Germs, Genes, and the "Immigrant Menace", New York 1994, pp. 84-95, 303-305; Howard Markel, Quarantine! East European Jewish Immigrants and the New York City Epidemics of 1892, Baltimore 1997, passim.

2 Edward Mormon, 'Guarding Against Alien Impurities: The Philadelphia Lazaretto, 1854-1893' in

Pennsylvania Magazine of History and Biography, 108 (April, 1984), p. 151.
} 
migrating to the United States ${ }^{3}$. Guardians of public health and national integrity may have adopted the new scientific discourse. But as emergency response teams in fear of killer epidemics, as guards standing at border crossings, or as campaigners for restrictive immigration legislation, these guardians followed a traditional rule of survival: safe is better than sorry, especially when the incomer or resident "foreigner" seemed to match a harmful or dangerous ethnic or racial profile.

New tools of diagnosis had clearly outstripped pharmacological efforts to cure infected patients and to eliminate contagious diseases before sulfa drugs and other antibiotics came into use during the Great Depression and the Second World War. There was thus a significant gap leaving all sorts of decisions affecting public health to administrative and political "solutions", These were reached often in the face of experience or of new scientific findings, especially in times of real or imagined panics about contagion; they usually remained soaked in biological determinisms which, in no small measure, were shaped by popular forms of neo-Lamarckism.

It is therefore important to appreciate that most practitioners of biology and medicine, while working in a Darwinian mode, seemed to have taken for granted all sorts of notions about the inheritance of natural as well as of acquired characteristics. While preoccupied with Sigmund Freud's Jewishness, Yosef Hayim Yerushalmi's insight illuminates an entire bio-cultural landscape. "Deconstructed into Jewish terms what is Lamarckism if not the powerful feeling that, for better or worse, one cannot really cease being Jewish, and this not merely because of current anti-Semitism or discrimination, and certainly not because of the Chain of Tradition, but because ones fate in being Jewish was determined long ago by the Fathers, and that often what one feels most deeply and obscurely is a trilling wire in the blood." Freud, in writing about the Land of Israel, was more circumspect: " we hail from there ... our forebears lived there for perhaps a whole millennium ... and it is impossible to say what heritage from this land we have taken into our blood and nerves ${ }^{4}$."

Indeed, in an era when so much public sentiment in governing circles wanted to restrict immigration from "barbaric lands", to use a phrase popular with labour leader Samuel Gompers, changing biological concepts about contagion and quarantine were easily influenced by traditional assumptions of moral agency, race, nationality, class, and religion. Howard Markel, a physician and historian of the typhus and cholera panics in New York City in 1892, recently put this point sharply when he wrote of a "mentality of quarantine" when "the infectious disease become [s] the enemy but so, too, do ... human beings (and their contacts)". Such a mentality contains the driving energy to use police power "to do everything possible to prevent the spread of an epidemic, often at the neglect of the human or medical needs of those labelled contagious ${ }^{5} . "$

\footnotetext{
${ }^{3}$ William H. McNeill, 'The Flu of Flus', in New York Review of Books, 47 (10 February 2000) p. 29; Martin V Melosi, The Sanitary City: Urban Infrastructure in America from Colonial Times to the Present, Baltimore 2000, pp. 103-204; Richard J. Evans, Death in Hamburg: Society and Politics in the Cholera Years 1830-1910, New York 1990, pp. 262-284.

${ }^{4}$ Yosef Hayim Yerushalmi, Freud's Moses: Judaism Terminable and Interminable, New Haven 1991, p. 31, but see also p. 52, and pp. 87-90; Richard J. Bernstein, Freud and the Legacy of Moses, New York 1998, pp. 110-113; Peter J. Bower, Evolution: The History of an Idea, Berkeley 1983, pp. 243-256; The Eclipse of Darwinism, Baltimore 1983, 1992, pp. x and xv, p. 89, p. 284 ; Ernst Mayr, The Growth of Biological Thought: Diversity, Evolution and Inheritance, Harvard 1982, pp. 356-357; George. L. Mosse, Toward the Final Solution: A History of European Racism, New York 1978, pp. 16,18-19, 35. Neo-Lamarckism had its own national contexts. For the United States see Alpheus S. Packard, Lamarck: The Founder of Evolution: His Life and Work, New York 1901, passim] George W. Stocking Jr., Race, Culture, and Evolution: Essays in the History of Anthropology, New York 1968, pp. 234-269. For examples of Lamarckian-like biological determinisms in earlier contexts and public health paradigms see Conway Zirkle, 'The Early History of the Idea of Acquired Characteristics and of Pangenesis', in Transactions of the American Philosophical Society, 35, Pt. 2 (1946), pp. 91-151.

5 Markel, pp. 185-186; Charles E. Rosenberg, The Care of Strangers:The Rise of America's Hospital System, New York 1987, pp. 297-309.
} 


\section{Section II.}

On July 28,1911, Der Kibetzer, a New York Yiddish-language Punch, published a cartoon ${ }^{6}$ showing cholera as an angel of death hovering between sky and water over New York harbour, facing Ellis Island and the United States chief immigration control officer, who is alarmed at the prospect of losing his deportation work to the killer. It clutches an immigrant steamship in each of its bony hands and dumps passengers from one of them into the open mouth of a nearby overflowing crematorium - a crematorium in New York Harbor, chimneys belching black smoke in Liberty's Bay!

Obviously Der Kibetzer spoke most direcdy to migrating Jews in steerage, who could hardly be expected to appreciate the concerns of class and ethnicity-conscious officials guarding national borders from potential lethal enemies. After the American Civil War cholera epidemics had broken out while, on German railways, Jews migrated towards Prussian heartiands. There, the recendy formulated germ theory of disease was being used to reshape public health perspectives about guarding the national border. This led to intensified efforts for devising protective screens. With sealed railway carriages, Germans organised steam-powered Wanderstrassen, which included medical control points and ended at guarded overseas passenger terminals and kosher kitchens in Hamburg's harbour. To migrating Jews and their justified sense of paranoia it was all but self-evident that Russian, Austro-Hungarian and German officials and clerks at border crossings, railway stations, and harbour facilities usually conspired to examine each person and each piece of Jewish baggage as if each was especially fit for a special quarantine. Mary Antin dramatically recalled her medical examination amidst hissing steam. She was stripped naked in front of strangers in white uniforms apparently threatening her in German. This Russian Jewish girl, a first generation migrant among her people en route to the American promised land, was so frightened she expected to be murdered. She then realised that there was no German policy to do away with her. "Hurry, hurry or else..." she had heard, losing the crucial subsequent phrase called out by the sanitising attendant in white: "or else you'll miss the train ${ }^{7} . "$

At the end of the journey across the Atlantic, the health service in New York's harbor became the final threat. Its web of detection spanned the United States Marine Hospital Service, hospital ships, disinfection barges, outlying beaches, and harbor islands. If a steamer came into the Lower Bay flying the yellow flag signalling cholera victims on board, physicians and their bacteria hunting helpers, with a "police boat patrol" hovering "about all day", went to work protecting the republic from the threat in steerage. Each passenger, was now regarded as a potential killer and isolated for the duration of lethal potency. Some died on board ship or in quarantine.

Many remembered, years after the event, as reported by the New York Times, the "Cholera scare in 1893. On Aug. 4, the Karamania arrived and reported three deaths from cholera on the voyage. The passengers were quarantined on Hoffman Island. The survivors were released on Aug. 24. There were 430 alive of the original list of 471." Eighteen years later, the crematorium was still burning bodies "as a sanitary precaution", to quote a small fragment in another New York Times story from 1911 about the delivery of two urns of ashes from Swinburne Island which was also controlled by public health officials ${ }^{8}$.

Jews had good reason to fear European and American public health policies. For centuries they had often been entangled in the bio-cultural obsessions of different times and

\footnotetext{
${ }^{6}$ The author wishes to thank the late Professor John J. Apple of Michigan State University for sending him a copy of this cartoon. He is the author of Jews in American Caricature: 1820-1914', in American Jewish

History, 21 (September 1981), pp. 103-133. His extensive collection of original cartoons and slides are in the John and Selma Apple Collection of Michigan State University Museum in East Lansing.

${ }^{7}$ Mary Antin, From Plotzk to Boston, New York 1985 [Reprint from 1894], pp. 37 and 41-43.

${ }^{8}$ NewYfork Times, 6 August 1893; 23 July 1911; 1 August 1911.
} 
places $^{9}$. When the Kibetzer cartoon appeared in 1911, its publication coincided with commercially profitable mass transport linking Europe with the ports of the Atlantic basin. Jews migrated west in their hundreds and thousands, from the Duchy of Poznan within the German Empire, from Galicia in Austro-Hungary, from the Russian Empire and from Lithuania in the decade before the First World War. They crossed great divides of nations, cultures, class, and of border screens separating one state from another. They encountered hostile stereotypes. In addition to intensifying nervous apprehensions among receiving populations about the impact of the Jew on their political economy and in the face of new forms of anti-assimilation pressures, there was wide-spread apprehension among frustrated, upwardly mobile Jews whose families, decades earlier, had come from Poznan and other western parts of East Central Europe regarding the influx of poor and unassimilated Jews that might threaten their own status. It was also assumed that, as migrants from the Asiatic East, Jews were potential carriers of dangerous diseases and epidemics ${ }^{10}$.

For the guardians of a receiving nation and neighbourhood who were already preoccupied with criteria of genuineness, trustworthiness and reliability these arrivals stimulated efforts to modernise old profiles for Jews. Conveniently at hand were changing national biomedical cultures in Europe and America. Articulate doctors were often at the cutting edge, as in the case of Sigmund Freud who rejected much of the race thinking so popular among his fellow physicians. The writings of Jews in this group demonstrate the point especially well. German and Austrian authorities, in part because they were convinced about the uniquely diseased nature of each Jew's body and mind, usually presented deaf ears and blind eyes to the work of Jewish colleagues. They consistently ignored what they considered inherently untrustworthy Jewish evidence which, in fact, challenged many of the negative findings about Jews in particular and race in general ${ }^{11}$. On the other hand Jewish physicians almost always reflected their own versions of Lamarckian beliefs. Euro-American physicians among Freud's contemporaries still attributed to Jewish men and women all sorts of peculiar characteristics and habits ${ }^{12}$. Experts continued to construct Jews as being impervious to the different climates and lifestyles in which they lived. Racial immunity or "a hereditary aversion to liquor" protected them from alcoholism; they also had not succumbed to plague and pestilence "to the same extent ... as had non-Jews". In similar fashion, but usually determined by the current events of their practice, doctors often made assumptions about the Jewish stranger or neighbour next door, widely believing all sorts of things, for instance that they were not as susceptible as Gentiles to typhus, tuberculosis, cholera, measles, scarlet fever, diphtheria, or croup. They believed that Jews suffered from diabetes, lung and bronchial problems, haemorrhoids, cancer "but neither penile nor uterine, due to male circumcision", conjunctivitis, trachoma, and colour-blindness in proportions significantly higher

\footnotetext{
9 John Block Friedman, The Monstrous Races in Medieval Art and Thought, Cambridge, MA 1981, pp. 31-32, 54—55, 69, 88; Davyd Greenwood, Nature, Culture, and Human History: A Bio-Cultural Introduction to Anthropology, New York 1977, pp. 38-41,107-126; B. Netanyahu, The Origin of the Inquisition in Fifteenth Century Spain, New York 1995, pp. 1082-1084 and 1145; Henry Kamen, 'The Secret of the Inquisition', in New York Review of Books, vol. 43 (1 February 1996), pp. 4-6; Carlo Cipolla, Miasmas and Disease: Public Health \& the Environment in the Pre-Industrial Age, Yale: 1992, pp. 4-5; David S. Katz, The Jews in the History of England 1485-1850, Oxford 1996, p. 108; David B. Davis, 'Jews and Blacks in America', in New York Review of Books, 46 (2 December 1999), p. 58; John Efron, Defenders of the Race: Jewish Doctors \& Race Science in Fin-De-Siecle Europe, New Haven 1994, pp. 6-7; Yerushalmi, Freud's Moses, pp. 32-33; . Sander L. Gilman, The Case of Sigmund Freud: Medicine and Identity at the Fin De Siecle, Baltimore 1993, pp. 11-20.

10 Jack Wertheimer, Unwelcome Strangers: East European Jews in Imperial Germany, New York, Oxford 1987, pp. 14-15 and 24-26. Between 1905 and 1914 over 700,000 Jews left German ports. Between 1871 and 1914, 5.8 million non-Germans left North Sea ports legally. Of these as many as one half were probably Jews, ibid. See also Shulamit Volkov, 'The Dynamics of Dissimilation: Ostjuden and German Jews'; Steven E. Aschheim, 'The Myth of "Judaization" in Germany', in Jehuda Reinharz and Walter

Schatzberg (eds.), The Jewish Response to German Culture: From the Enlightenment to the Second World War, Hanover, New England 1985, pp. 195-211 and pp. 212-241.

11 Efron, passim.

12 This was particularly true of doctors who were convinced of significant connections between mental illness and sexual practices, Efron, p. 7.
} 
than non-Jews ${ }^{13}$. Indeed, in Germany's influential biomedical culture social construction of disease and illness led to the general conclusion that Jews, though as individuals belonging to the white race, collectively constituted a separate race - pure, bifurcated, mixed, or racially separate by virtue of its unique religious community ${ }^{14}$.

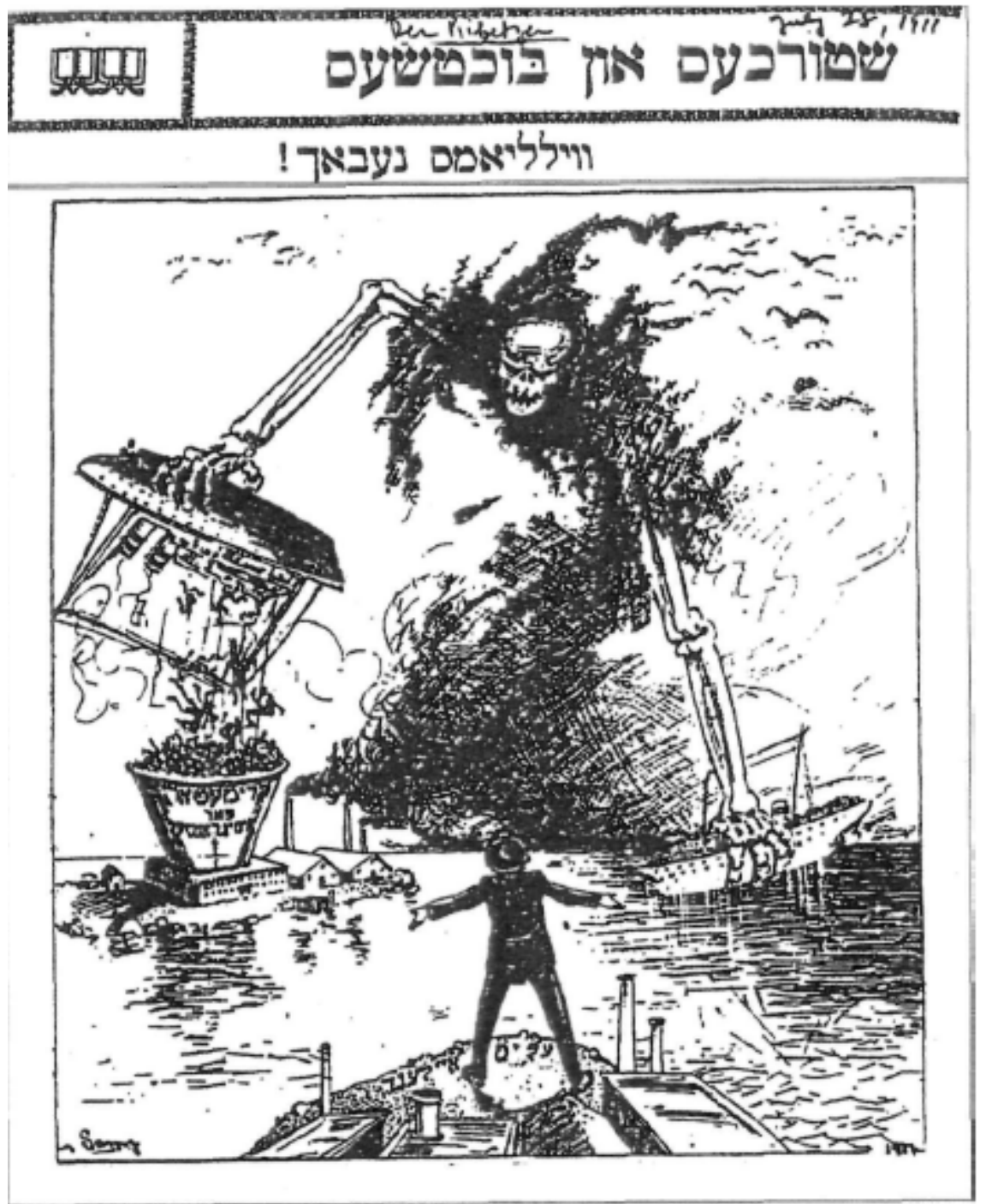

DerKibetzer, 28 July 1911

The Yiddish caption of this cartoon - loosely translated - reads as follows:

\section{Poor Williams!}

Deadly Cholera grabs each ship even before it approaches Ellis Island and hurls it into the crematorium. [The immigration Chief Inspector William] Williams stands at the edge of the ocean and his heart cries out for the unfortunate victims. He says: "If cholera continues for long I won't have anyone to send back. I'll lose my job. Oh! how I feel for the poor, unfortunate victims."

13 ibid., p. 27.

14 ibid, pp. 16-26. 
This kind of construction was embedded in the perspective of profile-oriented physicians who were charged with the responsibility of guarding the nation's wellbeing and integrity. The long period of conflict and uncertainty over fundamental questions of inheritance had precluded the quick establishment of a body of verified knowledge which would effectively challenge popular and professional beliefs and convictions from the past. On the one hand there was the continuing impact of beliefs that should have been discarded, as Ernst Mayr stressed when he evaluated the opposition to August Weismann's work among biologists: his "revolutionary rejection of soft inheritance encountered great hostility. It was attacked not only by the neoLamarckians, who reached the height of their influence in the 1880s and 1890s, but even by orthodox Darwinians who continued to accept Darwin's occasional reliance on the effects of use and disuse". Weismann, according to Mayr "had probably, up to the 1930s, more adherents in England than in ... [his] home country. Near universal acceptance did not occur until the 1930s and $1940 \mathrm{~s}^{15} . "$

On the other hand there was bacteriology and its findings. Once organisms were isolated, identified, and linked to specific contagious human diseases such as anthrax, tuberculosis and cholera the new approach was ready-made for emerging interventionist governments trying to cope with the impact of a steam-powered international economy. In the United States, public health officials had started to treat all passengers "as potentially pathogenic". At Prussian control points, official campaigns "assumed the guise of a systematic war against an identifiable enemy carried out under the clear direction and supervision of specialist medical scientists. Even the voidance of personal contact was now given scientifically validated form in the destruction of the bacillus through medically approved actions such as washing, disinfection, boiling water, and so on". In other words, while believing in the inheritance of personal and collective characteristics, be they "natural" or "acquired", the practitioners modern scientific eye now looked upon each traveller as a potential killer ${ }^{16}$.

In the United States these convictions and patterns of perceptions in public health policies, existed in an environment of deeply rooted and widely accepted forms of American biocultural obsessions. Beyond the imposed "normal" separation of blacks and whites, self appointed guardians of an idealised white Anglo-American society used a terrifying lynching crusade in the "deep south" to institutionalise post Civil War segregation throughout America's southern region. Having first been devastated by campaigns of pacification, indigenous Americans were penned up in patrolled reservations. The republic also continued to manifest its special hostility towards Chinese migrants by adopting and sustaining special laws of exclusion applicable only to them ${ }^{17}$.

So it is not surprising when in 1892, New York City, scared by fear of epidemics involving typhoid, typhus and cholera, struck incoming Jews from Europe with special force. Jews were arriving in the city in much larger numbers than ever before. The sanitary inspectors, physicians, and a special police force in the city's Division of Contagious Diseases in the Health Department were mobilised to protect the metropolis from catastrophe. They were also Jewconscious germ-chasing officials with extraordinary powers, akin to the authority of a few state and federal officials who could impose martial law It was the kind of empowerment and

\footnotetext{
15 Richard Quain et at, A Dictionary of Medicine, New York 1883, p. 532; Mayr, pp. 356-357; Nancy Stepn, The Idea of Race in Science: Great Britain J800-1960, Hamden 1982, pp. 85-86.

${ }^{16}$ Evans, pp. 271 and 477; Rosenberg, p. 140ff.; Mormon, p. 151. For a careful discussion of this complex subject in Germany see Paul Weindling, Health, Race and German Politics between National Unification Nazism, 1870-1945, New York 1989, pp. 11-269.

17 John Carey, The Intellectuals and the Masses: Pride and Prejudice among the Literary Intelligentsia 1880-1939, New York 1992, passim; Asa Briggs, Victorian Cities, London 1963, pp. 168-234; Paul Boyer, Urban Masses and Moral Order in America 1870-1920, Harvard 1978, pp. 123-283; Joel Williamson, 'Wounds Not Scars: Lynching, the National Conscience, and the American Historian', in Journal of American History, 83 (March 1997), pp. 1236-1238; Leon F. Litvvack, Trouble in Mind: Black Southerners in the Age of Jim Crow, New York 1998, pp. 179-341.
} 
enforcement which caused panicky outcries in the Yiddish press comparable to Mary Antin's fear of being murdered in Prussia ${ }^{18}$.

\section{Section III.}

In fact the screens and quarantines were applied under the guise of the supposed public good. Public health officials thus felt justified to routinely use all sorts of protective procedures. Cremation was one of them. The crematorium on the artificial Swinburne Island in the Lower Bay of New York harbour had been authorized in 1888, when, under the impact of miasma theory, burial grounds still remained suspect of contagious virulence. New York's public health officials had managed to persuade the state legislature and governor to pay for "a crematory ... for the incineration ... of the bodies of persons dying at Quarantine for contagious or infectious diseases ${ }^{19}$."

Many remembered, years after the event, the cholera scare in 1893, as told by the New York Times. The vessel Karamania - already mentioned in connection with that episode - carried mostly Italians, and so did two other ships which had actually contributed to the death toll of forty-one on board ship in quarantine. The two urns of ashes - also mentioned in reports by the same paper - were the remains of a former New York City street cleaning commissioner who had died of yellow fever "his body had been cremated as a sanitary precaution". The oven had been busy, but not as a special weapon of public policy against Jews or any other group. New York law specified that the "health officer ... shall cause to be incinerated ... the bodies of persons dying at the quarantine hospital from the infectious diseases, except of persons whose religious views as communicated by them while living, or by their friends within twenty-four hours after their decease, are opposed to cremation ${ }^{20}$."

Incineration of private property was another procedure. During the cholera scare of the spring and summer of 1892, as part of an emergency disinfection sweep, Manhattan's health officials had the legal authority to take and destroy private belongings without restitution or compensation. So when a Mrs. McGrath was hit by typhoid fever the city burnt her "bed and Featherbedding". A year later she lodged a formal complaint in vain to the Mayor for, she claimed, she was still without a "bed to sleep nor anything to cover". Hermann M. Biggs, the distinguished Chief Inspector of Pathology, Bacteriology \& Disinfection, confirmed that her bedding had been exposed to infection and was "destroyed in accordance with the directions of the Board [of Health] governing such cases". Therefore, the Board informed the Mayor's Office, it "cannot approve of any claim for payment for the same ${ }^{21}$."

And the city's dog pound protected citizens from stray dogs suspected of rabies by gassing them, allegedly a less cruel method of killing than the shooting of captured animals. There is an "airtight Box made of Wood and lined with zink the size of $9 \mathrm{ft}$ long $5 \mathrm{ft}$ wide and $3 \mathrm{ft}$ 6 in high into which a 1-^- in gas pipe is connected to supply the ordinary illuminating Gas, and the capacity," reported the Keeper to Mayor Hugh J. Grant, "for holding about 120 Dogs ... when t ey are put in. The gas is turned on allowing about Eighty feet of Gas to fill the box, which takes

\footnotetext{
18 Markel, passim. Reporting on the coerced removal by health inspectors, a New York World account talked of the Jewish "patients ... ignorant and already cowed by oppression" as individuals "being hurried to execution for all they knew". The Yiddish-language Arbeiter £eilung reported "alarming screams and outcries as if ... children and relatives were being taken to the slaughterhouse", Markel, pp. 50 and 52.

19 J.M. Hawley to Abraham Hewitt, April 2,1888, N.Y Attorney General's Office to F.L. Dallon, 25 May 1889, Folders: Health Dept, 1888, OF-1892, Box 88-GH-21, NYC Municipal Archives (hereafter MA).

${ }^{20}$ New York Times, 4 September 1892, 6 August 1893, 23 July, 1 and 3 August 1911; Deed to the NY Quarantine Station and copy of passages of New York State law governing the activities of the Station, in Hugh Smith Cumming, U.S. Surgeon General to L. E. Cofer, 25 February 1921. The Quarantine Station's correspondence for this period is part of the collection generated by the Treasury Department. Accession \# 65A-233, 330-8300, Box 509093, RG 90, National Archives, Bayonne, NJ (Hereafter NA/B).

21 M.Jackson, MD to Hon. Thomas Gilroy, 28 August 1893, Hermann M. Biggs to Ghas. G. Wilson, 1 September 1893, Secretary, Health Department to William Holly Esq., 5 September 1893, Folder: Health Dept, OF-1892, Box 88-GH-21, MA.
} 
about four minutes, by that time the Dogs are asphixiated, after which we allow them to remain in the box for about ten minutes, and then we draw off the gas by a 4 in ventilating pipe and a draught valve on the bottom of the box ${ }^{22}$."

Fumigation and quarantine were also enforced when the threat from germs did not come from foreign incomers; indeed, the treatment of returning soldiers, who had served in battle under the American flag, best reveals normal emergency responses by health officials. At the close of the Spanish-American War, when segregated black and white American soldiers from abroad were believed to pose a health threat, including Theodore Roosevelt's "Rough Riders" and young Harvard men who belonged to elite families, the public good was served by isolating them in Montauk, at the opposite end of Long Island ${ }^{23}$.

Some 22,000 of these soldiers, having been quickly evacuated from Cuba, were delivered into the hands of officials entrusted with the guardianship of the nation. From the start there were problems of organisation and preparedness. Doctors George M. Magruder and his deputy Joseph P. Kinyoun, in command of the assigned federal quarantine unit, had to navigate among competing authorities such as their own surgeon general in the Department of the Treasury, the army's surgeon general, officials in the navy in charge of transports and patrol boats, the secretary and his assistant secretary of the War Department, the health officials in New York City, and the governor of New York. Initially Magruder reported, "it was proposed to place the detention hospital in charge of officers of [his] Marine Hospital Service, but to avoid complications which threatened and to prevent the unsatisfactory and inefficient work which too often attends division of authority, it was considered best to adhere rigidly" to the decision "that my authority over troops and vessels should terminate when the yellow flag was hauled down". In fact, just before the transports began to land, issues of rank, jurisdiction, pride, prestige, and professional competition between ranking Marine Hospital Service doctors and army doctors all but dictated the arrangements that Magruder glossed over in his final report. His jurisdiction, however, would stop at the waters edge ${ }^{24}$.

A harbinger about preparations had come a few weeks before the first transport arrived at Montauk's Wikoff Camp. The Concho was quarantined for three days at Hampton Roads, Virginia with many typhoid victims on board, amongst them soldiers from the Cuban coast struggling with "exhausting malarial fever" and many others "recovering from the yellow fever hospitals at Sibonay". From there the transport sailed into quarantine in New York harbour, which meant the Concho would be handled like a vessel carrying immigrants diagnosed as suffering from illness or being suspected of harboring a contagious disease. Upon arrival the Concho was thoroughly disinfected. It was decided that "most of the officers and passengers might be landed later while all but fifty-nine of the others, too ill to be moved, should be taken to Hoffman and Swinburne Islands". At Swinburne that day one of the soldiers died of typhoid fever. The Times reported that his "body will be encased in a hermetically sealed casket and brought to the city". The vessel with its soldiers remained in quarantine but, unlike the very ill taken from immigrant ships, the soldiers on Hoffman and Swinburne were moved to new quarters at the quarantine station on Staten Island.

The Times also reported the reactions of some of the quarantine employees. They described conditions comparable to steerage in summer time. "Emaciated men lay in hard bunks, burning with fever. Some had only undershorts or a pair of drawers." In other words the Concho,

\footnotetext{
225 July 1892. The Mayor had requested the information to answer a question put to him by the president of the Board of Commissioner in the District of Columbia. On 30 June 1892 he wanted to know how New York killed its impounded animals because he had complaints about the "alleged cruelty" in shooting them, ibid., GHJ-8, MA.

${ }^{23}$ New York Journal, 1 September 1898, in Jeff Healy (ed.), Bully: Colonel Theodore Roosevelt, The Rough Riders and Camp Wikoff, Montauk 1998, pp. 5 and 196-200; see also Elting E. Morison et al, The Utters of Theodore Roosevelt, Cambridge, MA 1951, II, pp. 842-843, 851, 852, 854, 855, 865; New York Times, 4 August 1898; Annual Report of the Supervising Surgeon-General of the Marine Hospital Service of the United Stales, Washington 1899, pp. 622-623 .

24 ibid., p. 625; George M. Magruder to Surgeon General Walter Wyman, 17 August 1898, MHS, RG 90, National Archives (hereafter NA).
} 
and later some of the other transports had not been properly equipped or staffed to transfer the returning soldiers, including some of the sons of the richest and most influential Americans. Dr. Monae Lessing of the Red Cross, although appreciating the military emergency, was appalled: "Everybody apparently supposed that the vessel had proper stores. But there were no medicines, no disinfectants, no ice, no fresh water, no mattresses, little covering. The men ... were put between decks to sleep on hard bunkers, where little fresh air could reach them." In other words the vessel was a breeding box for the contagious diseases so feared by the quarantine service ${ }^{25}$.

Soldiers from a battle zone rife with malaria, yellow fever, typhoid, and typhus were arriving at a U.S army camp which did not have the necessary infrastructure in place. As happens so often with surges of contagion threatening to endanger public health, emergency response groups found themselves stretched well beyond their expectations; for besides incompetence, neglect, and capriciousness they had no or very little control over the infrastructures and the logistics required to fight such an emergency. The Long Island Rail Road had to extend its rail connections to a long sought terminus in Montauk. The World and the New York Herald reported:

About three hundred men appeared on the scene yesterday, with horses and cart and picks and shovels. The railroad, which stops short eight miles before it reaches the tip of the Point where the troops were to be unloaded, sent down carloads of lumber and ties and railroad iron. The workmen had to bring food for themselves and their horses, for there was none to be had in the wilderness. These men have been rapidly laying clown tracks, making roadways and putting up houses. ... Linemen are [also] at work stringing wires between [nearby] Bridgehampton and this place. ... There is now one direct wire between here and New York, but within two days there will be four wires in service ${ }^{26}$.

But according to a summer resident from nearby Southampton, who at the time was a national senior official and field agent of the Red Cross, work on tent and store house construction, as well as on reliable water facilities was so far behind schedule that Camp Wikoff remained unprepared for days after the troops started to arrive. Indeed, a few months after the closing of the camp, the Red Cross official was still appalled by what had happened to the general hospital: it was "constructed day after day, almost over the heads of the sick men"; work "was going on almost until the day when the order came to clear out the hospital ${ }^{27}$." By early September, many a local resident feared the camp was a veritable breeding ground for typhoid and typhus. So did doctors. Nicholas Senn, an army doctor criticised his colleagues and superiors:

All the conditions for an epidemic were in place. Water pumps were failing even as doubts about the reliability of the well water itself remained. Poor discipline led to exposure to human and animal waste. Stagnant pools of water near the soldiers' tents were filled with excrement from horses. Flies abounded. Wagons carried uncovered stacked loaves of bread through the dust covered camp. And there was no working hospital laundry to prevent the accumulation of "foul linen" - in the end they had to be burnt ${ }^{28}$.

Another doctor, visiting the Presbyterian and Bellevue Hospital, after having visited the camp, exploded to a reporter for the New York Times. Disinfection at the camp is a "farce. The whole camp is infected with disease." Typhoid fever takes two weeks to develop. That's why

\footnotetext{
${ }^{25}$ New York Times, 1-3 August 1898.

${ }^{26}$ Healy, pp. 25-27, 32-37.

27 At the time Townsend was acting as volunteer field agent. American National Red Cross Relief Committee Reports, 1898-1899, pp. 227-228.

${ }^{28}$ Red Cross Report, p. 226.
} 
typhoid cases have shown up in the city's hospitals; these were brought by soldiers from Montauk who had never been hospitalised or who had been furloughed, free to try to walk the streets of Manhattan. "Proper sanitation is what they don't understand there." The spread of typhoid fever "is perfectly preventable... just as much as cholera, and yellow fever ${ }^{29}$."

Obviously, contagious diseases had been a serious problem at Wikoff. Yellow fever had not been the culprit; it had been the "other sick", the "ordinary cases of sickness, such as malarial fever, typhoid fever, etc." that had presented the danger to all those who feared them, especially typhoid fever and typhus, illnesses often difficult for even a trained eye to diagnose with precision or tell apart one from the other. Ninety-eight out of the one hundred and fifty soldiers who died, and were buried, at Wikoff had their cause of death listed as typhoid ${ }^{30}$.

Against this background it is clear that the quarantine imposed on Jews a few years earlier had been part of the routine of quarantine but it had been quarantine with a difference. In March 1892 victims of typhus in one Jewish residential quarter had been traced to a recently arrived vessel from Europe. Upon them, on other Jewish passengers, and on the nearby Jewish places they frequented, swooped quarantine officials along with the ruthlessness, incompetence, and capriciousness so characteristic of the emergency response efforts. In no time at all, and given the prejudice towards impoverished recent arrivals living in unsanitary overcrowded conditions, all sorts of anti-Jewish language made its way into official reports. According to Cyrus Edson, Manhattan's chief sanitary inspector and quarantine enforcer, Jews were "phlegmatic, dull, and stupid ... sullen and suspicious". When it "comes to a question of disease, they will ... do anything ... and lie with the most magnificent elaboration as to all matters touching their own sickness or those of their neighbors". Indeed, reports Markel, who studied this quarantine closely, "the popular perception among many native born New Yorkers was that the Lower East Side was a breeding ground for pestilential disease ${ }^{31}$."

But the quarantines achieved a measure of success. In the Spring of 1892, typhus in the Jewish Lower East Side remained contained. In 1898, yellow fever did not spread from Cuba to the mainland, and disease from the sick interned at Wikoff was also contained. Officials claimed police control had helped. For example, around the troop carriers military discipline kept intruders out, even an eager patriotic physician from Springfield, Massachusetts. He had tried to bring food packages to "his boys", the 2nd Regiment of Massachusetts Volunteers, on board the returning, now quarantined, troop carrier St. Louis. As his launch in the Long Island sound started to come alongside, he faced rifles ready to fire at him if he did not turn away ${ }^{32}$.

This incident with the doctor pointed to three important differences between Wikoff and the way public health officials related to Jewish immigrants. The doctor, technically an agent of Springfield's Auxiliary Branch of the Massachusetts Volunteers Aid Association, sent a long complaint to Washington about Wikoff's quarantine enforcements. Its senior quarantine officer responded with a point by point refutation: the physician's treatment by the officer in charge was an act flowing from authorised public health policies designed to protect the republic.

Secondly, albeit only on its own terms, the army had encouraged care packages and all sorts of other assistance from the "outside". It eagerly sought and received the help of the American Red Cross for fresh water supplies and other perishables. The field commanders even accepted its female nurses and other personnel, although the officer in charge "like all army

\footnotetext{
29 New York Times, 2, 3, 4, 5 September 1898; Red Cross Report, p. 237. See also A. R. Tooth, a medical service worker in the camp, protesting to Wyman about standards of health and control: 23 August 1898, MHS, RG 90, NA.

30 Healy, pp. 499-508.

31 Markel, p. 33. See also ibid., pp. 50-59, 62-75, 113, 119, 132-133 for other anti-Jewish references during the following months and year.

32 David Clark MD, Springfield, Mass., to General Greenville M.Dodge, President of Commission for Investigation of Conduct of War, 3 October 1898; Magruder, Camp Hutton, La., to Surgeon General Walter Wyman, October 14,1899, Marine Hospital Service, RG 90, NA.
} 
surgeons of the old school ... was prejudiced against them;" without them the camp would have been hard pressed to cope with the army's unpreparedness to handle embarking troops from inspected ships. It also allowed the Red Cross to distribute care packages from friends and relatives of the encamped soldiers. In addition there were many visitors, parents or siblings from afar and patriotic residents from nearby ${ }^{33}$.

Implicit was the most important difference. In comparison to Jewish immigrants associated with contagious diseases, the soldiers were not held responsible for their illnesses or circumstances, not in the camp, not in stations of the Long Island Railroad, and not on Manhattan's streets, where some of them collapsed. They were not considered phlegmatic, dull, or stupid. Indeed Roosevelt made certain that he and his fellow soldiers were perceived as heroes as did President William McKinley who, having visited the site, launched an investigation of the Wikoff experience. (It found no evidence of unusual negligence or incompetence in the activities of any federal agency involved.) Blame was assigned to military officialdom and circumstances, or sometimes to incompetent doctors or the enforcers of quarantine rules ${ }^{34}$.

The different approach was not limited to the 1890s; it remained embedded in the quarantine structure. Indeed events a few years later foreshadowed the future. Notwithstanding the experiences and criticisms of the quarantines on Long Island, under Surgeon General Wyman's authority, the well trained and respected bacteriologist, Dr. Joseph P. Kinyoun who had long been a deputy to Wyman and who had worked at Wikoff, imposed a punishing quarantine against bubonic plague on San Francisco's Chinese and Japanese residents. Before a federal court order ended it, his race-based cordon sanitaire was reminiscent of Edson's emergency decrees for Jews of the Lower East Side ${ }^{35}$.

\section{Section IV.}

In 1911, the Kibetzer's cartoonist and his kinfolk had assumed that there was hostility among European and American officials towards themselves as Jews. Since the end of the century, the proportion of those kept out for medical reasons had gone up from less than $2 \%$ to $57 \%$ in 1913 , and up to $69 \%$ three years later. More important still, especially from the perspective of the new incomer, there were the explosions of suspicion about distrusted immigrants and deadly contagious diseases understood in terms of germ theory. In this new perspective ghettos were seen as dangerous breeding grounds with a difference, presumed worst in San Francisco among the Chinese, but presumed present also in Philadelphia and New York among Italians and Jews. Still, in spite of the rise of modern political anti-Semitism there were also many reasons for being hopeful. By 1911 many more Jews had arrived and, together with older immigrants, they were acquiring more economic and political influence, especially in New York City where most of them were concentrated and where they shared with everyone else expectations about the control or even elimination of lethal epidemics ${ }^{36}$.

But the law of unintended consequences had also been at work. Within a few years after 1911 there were indicators of profound change for the worse, especially from the perspective of any individual not protected by citizenship. Such persons were akin to creatures in the wild, fair game to any predator. Patriotic public health practices from the past persisted, becoming ever deeply enmeshed in the policies of the United States and of European countries preoccupied with the defence of perceived national cultures. Despite the advent of more reliable diagnoses of contagious diseases and of more experiences with fumigation and quarantine techniques, particularly in the years of war and revolution after 1914, profile screening continued to be used for selected incomers perceived as potential transmitters of typhus, typhoid, or cholera. In the

33 Report of the Supervising Surgeon-General, p. 621; Red Cross Report, pp. 229-230.

${ }^{34}$ Healy, pp. 61-72, 75, 138-140, 231-248.

${ }^{35}$ Kraut, pp. 79-96

36 ibid., p. 66. 
absence of reliable protective vaccinations, or the availability of sulfa drugs and antibiotics of a later generation, fear of diagnosed harmful bacteria mingled easily with rising tides of xenophobia, race consciousness, and inflammatory metaphors.

Indeed, in these years all sorts of hierarchies were emerging in European and American biological politics. Once the twentieth century science of genetics started to explain biological mechanisms for inheritance, Koch's kind of campaign to identify and contain, if not to control harmful bacteria in the human body, served as one influential model for achieving ideal states of public health for an envisioned national body politic; programmes of social hygiene and race institutes compared their "genuine nation" to a healthy human body and campaigned for policies that would protect their nation against particular groups of human organisms ${ }^{37}$. Between 1914 and 1921, war and revolution often intensified such perspectives. Moments of triumph for self determination, often in the aftermath of blood soaked battles, brought refugees in flight from regions associated with epidemics of contagious diseases. These were ideal conditions constructing and reconstructing public enemies, for propagating old and new metaphors with which individuals and peoples distanced themselves from each other: snakes and cattle, weeds and parasites mingled easily with bacteria, germs, and after 1917 with "nits and cooties", that is with lice and vermin often associated with Jewish migration from Eastern Europe ${ }^{38}$.

\section{Section V.}

Because so much of the post-war East European steerage migration headed for New York from battle zones in which typhus raged, die inadequate capacity of its port to handle the incomers reverberated throughout overseas medical control arrangements. The need for improvements had been obvious for some years but since 1916 the harbor's quarantine station was caught in a transfer process between the state of New York and the federal government. The final arrangements were not completed until 1 March 1921. Until then funds for expanding and modernising the facilities were not available.

In the event, the quarantine station, technically owned by New York but managed by Dr. Leland E. Cofer, a federal employee on loan to the station, was ill equipped for the task at hand. It was run down because New York, according to Cofer, had spent "very little money" on the station in "recent years". The buildings "are all in poor conditions and require extensive repair". The station had also found it hard to recruit personnel. According to Cofer the rate of pay at the station was lower than at local hospitals even though the work was more "exposed and strenuous". Fear of contagion was a constant problem:

\footnotetext{
${ }^{37}$ Weindling, pp. 270-395; Stefan Kuehl, The Nazi Connection: Eugenics, American Racism, and German National Socialism, New York 1994, pp. 13-48, 65-76; Michael Burleigh and Wolfgang Wippermann, The Racial State: Germany 1933-1945, New York 1991, pp. 23-43; Goetz Aly, Peter Chroust, and Christian Pross, Cleansing the Fatherland: Nazi Medicine and Racial Hygiene, Baltimore 1994, pp. ix-xiii, and passim. See also the late DetlevJ. L. Peukert in Thomas Childers and Jane Caplan (eds.), Reevaluating the Third Reich, New York 1993, pp. 234-249.

38 On metaphors for humans and insects during the First World War see for example Edmund P. Russell III, "'Speaking of Annihilation": Mobilizing for War Against Human and Insect Enemies, 1914-1945', in Journal of Ameiican History, 82 (March 1996), pp. 1512-1513. Years earlier "vermicides" - "a group of anthelmintics" - were used to kill "intestinal worms". After the First World War "Verminicide" was on the market in England for killing "vermin". For examples of the specific use of "verminous" with this meaning see the following: the first was written about English conscripts to explain typhus in the trenches, "The continuance of lousiness evidendy depends upon a low standard of life. ... It has been stated that the infection was started by new recruits who came from verminous slums, and the crowding together by troops and the limited facilities for bathing gave the parasites every condition favorable to multiplying and spreading." Folder Report I-XXXIX, Box 35, in Strong Papers "Infection with Vermin", 1. The second was applied to Bolsheviks. Alfred E. Cornebise, Typhus and Doughboys: The American Polish Typhus Relief, Delaware 1982, p. 136. The word "verminous" like "vermin" has a long pedigree which includes the following use in 1830: "Both in Russia and Poland I believe ... [Jews] are a verminous population preying upon others" as well as this one in 1899: "In 'verminous persons' the hair is sometimes matted together by pus, nits, scales and scabs." The Compact Edition of the Oxford English Dictionary, II, Oxford 1971, pp. 3614,4084 .
} 
[B]efore almost any kind of help will come to this station, the fear of quarantinable diseases must be quieted and a natural aversion to isolation on [die] Islands must be overcome. The result is that instead of having persons apply for position at this station we are continuously advertising for help in papers and in other ways hunting up persons for employment here ${ }^{39}$.

On its two quarantine islands there was just not enough room to meet the demand. "It is necessary that the capacity of the Station [100 sick with quarantinable disease and 1600 in detention for observation] should at least double throughout," Cofer wrote in a report for the president of the New York Academy of Medicine. Experience had taught that when several vessels arrived at the same time the station needed observation space for around 3,500 patients instead of the available 1,600. "In past winter when twelve ships arrived with typhus on board and eight with small pox," the station had to make "vessels ... lie at anchor in Quarantine with their personnel aboard, which not only constituted faulty quarantine methods, but was a personal hardship to the passengers involved and a distinct financial loss to the steamship companies and the community in general on account of the withdrawal from regular schedule of passenger vessels ${ }^{40}$."

Passengers had little choice and did not rebel ${ }^{41}$. They were confined in run-down, inadequate quarantine facilities where personnel used procedures marked by incompetence and sloppiness. Gofer had to admit to the Surgeon General that "lousy passengers were turning up in Ellis Island after having been inspected at Quarantine". He identified his problems in detail: "immigrants are caused to scrub up their bodies just before arrival at this port when they are caused to put on clean undershirts and then it would appear that the infested undershirt formerly removed is put back on the immigrant over the still clean undershirt and the immigrant naturally shows up lousy at the Ellis Island inspection." Mattresses and blankets presented another problem for which neither the budget nor the facilities allowed obvious solutions: "it has been found that immigrants accounted for as clean from this Station after spending two or three nights on probably already infested mattresses and under infested blankets can show up an increased ratio of uncleanliness at Ellis Island ... It would be a big project to send them through steam chambers. It could be done," he informed Washington, "but we are already overtaxed with 6-700 in quarantine. There is also the matter of time for tying up the vessel ..." And, Cofer reminded his superiors, even though he was offering "125.00 [dollars] a month without quarters and subsistence" he was unable to find additional men or women "to train in examining these people for body vermin ${ }^{42}$."

In these circumstances Cofer was also apprehensive about the streams of migrants now heading his way from Eastern Europe. They were returning to pre-war levels but with plague and typhus fever. These "were reported as existing especially in Russia and Poland to an alarming degree. Asiatic cholera was reported in the Crimean and other ports of the Ukraine." While he did not expect an immediate problem in New York, he was nervous: "if the report was true that there were 250,000 cases of typhus fever in Poland and 40,000 cases existing in the City of Lomberg [sic], then it was not unlikely that the foreign ports of departure would become infected ${ }^{43}$."

The interaction of structural circumstances in New York, when combined with apprehension if not fear of the post-war migrations, especially of Jews from Poland, prompted the Public Health Service to install a rigorous control system. At ports of embarkation with

\footnotetext{
${ }^{39}$ L. E. Cofer to R. H. Creel, Asst. Surgeon, General Bureau of the Public Health Service, Treasury Dept., 17 November 1920, RG 90, NA/B

${ }^{40}$ Cofer to E. W. Lewinsky-Corwin, 3 May 1921 with undated report attached, NA/B

${ }^{41}$ In contrast 38 crew members of the Antigone rebelled in New York harbour. Report attached to letter from Cofer to Creel, 22 June 1921, NA/B.

42 Cofer to Cumming, 28 April 1921, NA/B.

43 Lcland E Cofer, Report of the Health Officer of the Port of New York, 1 July 1920-28 February 1921, Typescript copy NA/B.
} 
hinterlands or contact with regions associated with contagious diseases, U.S. quarantine officers were expected to quarantine and clear all passengers headed for the United States. At American ports, a "most rigid system of medical examination of arriving passengers from Europe and thorough fumigation of vessels was inaugurated. Not only were vessels quarantined and persons exposed to infection detained when actual quarantinable diseases were found on arriving ships," reported Cofer in March 1921, "but extraordinary precautions were taken, as follows: In the first place, persons arriving from places suspected of infection with typhus were required to be deloused. Persons arriving from places where cholera was known to exist were required to submit to bacteriological examination of discharge prior to admission, and vessels from plague infected or suspected ports were required to be fumigated for rat destruction ${ }^{44}$." Clearly, the more effective and reliable the clearance procedures abroad the less pressure on the quarantine station in New York; and for that reason conditions in New York radiated outwards throughout the entire quarantine system at foreign ports of embarkation.

\section{Section VI.}

In those circumstances, which in some ways are comparable to events associated with Wikoff and New York City in the years around 1898, thousands of returning soldiers and migrating Jews were heading for quarantine in or near Danzig. After 1917, and for different reasons, the Baltic port city received special attention. Victorious diplomats and generals at Versailles in April and May 1919 and again in the summer of 1920 focused on this old Prussian commercial centre, its hinterland, and its rail connections to Warsaw, especially the section running from Thorn to Danzig ${ }^{45}$. American and European immigration restrictionists also watched its affairs. As opponents of Southern and East European migrants, they feared the aftermath of war. Restrictionists were convinced it would bring a resumption of mass migration towards the west. Until Americans adopted a new immigration law with its ceilings and racebased quotas - these were expected to all but stop Polish Jews from emigrating after May 1921, when the new law was to go into effect - concern focused in the intervening months on Danzig.

The returning soldiers consisted of a special army unit which had been deployed in Poland. It was an odd collection of about 12,000 soldiers who shared one characteristic: they were all Polish-American residents of die United States who, once America had joined the war, had been encouraged by officials of an emerging Polish government to fight for the newly independent Poland as volunteers in a Polish Legion. With its distinctive uniform this force had been attached to the French army, but after the armistice the Legion served in Poland under General Joseph Haller in his campaigns against Germans, in disputed territory subject to plebiscites, and against Bolsheviks, who were fighting Poles for sovereignty over the western Ukraine. In late 1919, during a lull in the fighting, these "Haller men", were discharged into limbo until early 1920 when a joint resolution of Congress authorised the "Secretary of War to use such army transports as may be available to bring back to the United States from Danzig, Poland, such residents of the United States of Polish origin as were engaged in the war on the side of the allied and associated powers." By March, the U.S. army's transportation service, operating out of Antwerp, took charge of the men's embarkation from Danzig and transfer to the United States, while in Poland the American Ambassador, his military attache, and his consul in Warsaw handled citizenship verification, organisational procedures, and arrangements for quarantine control prior to the troops boarding ship ${ }^{46}$.

${ }^{44}$ ibid.

45 Arno J. Mayer, Politics and Diplomacy of Peacemaking, New York 1967, pp. 95, 599-603, 759. There were some suggestions that Germany's border with Poland would be fixed to the west of that railway line so that the Allies could intervene in Poland independent of German policies. In August of 1920 Bolshevik units came within 30 kilometers of Warsaw.

46 Cornebise, pp. 101-102;. H. H. Ben Sasson (e<土), A History of the Jewish People, Cambridge Mass., 1976, p. 954; Joseph T. Hapak, 'Selective Service and Polish Army Recruitment During World War P, in Journal of Ethnic History, 10 (Summer 1991), pp. 
The quarantine control for the soldiers was assigned to the American Polish Relief Expedition. It consisted of another group of American soldiers who were in Poland as part of a larger effort to help the Polish government fight the widespread typhus epidemic in order to establish around Poland a cordon sanitaire. (The epidemic had been raging since 1916, when most Poles were, and would remain until the end of 1918, under German military occupation.) The American efforts had diverse elements to it, including the work of the Jewish Joint Distribution Committee, and, as part of the strategic goals of the relief programme, that of a scientific Red Cross mission, staffed by Harvard biologists keen on studying the typhus vector. The quarantine unit, now also heading for the vicinity of Danzig, was part of an emergency response detachment which had been formed after the armistice agreement. Its French headquarters were in Paris, its Polish centre of operations in Warsaw. It was led by Colonel Harry L. Gilchrist, a fifty-year-old physician with an MD from Western Reserve and training at the Army Medical School ${ }^{47}$.

Fighting among Poles, Ukrainians, and Bolsheviks had been most disruptive and had put an end to the important eastern part of the cordon sanitaire against typhus, threatening to do the same in the west. Retreating soldiers, reported Gilchrist to his superiors, destroyed much of the anti-typhus fighting equipment and, as large proportions of soldiers "were filthy and verminous", they "reinfected large parts of Poland which had been [made] free of the disease". Gilchrist's view of the future was bleak: without immediate aid, he insisted, "suffering will be intense and all Europe will be threatened with a terrible Typhus Fever Epidemic ${ }^{48}$."

The men connected with the Danzig embarkations knew what to keep out of the United States and were experienced to execute quarantine orders under the most chaotic of conditions. Gilchrist's number two, Doctor Lee R. Dunbar, was in charge. He had been head of the Bathing and Debusing Division of the American Third Army, and had most recently been posted to Lublin as an adviser to Polish health officials. He arrived on 18 March 1920 with the expectation that his first contingent would have to be ready to embark within a few weeks for the first troop carrier was due to arrive in Danzig on 23rd March ${ }^{49}$.

At first, Dunbar's military operation was obliged to make the final screen, delousing, and clearance for embarkation within Danzig, using the Danzig-Troyl plant, which the German army had operated ${ }^{50}$. The Polish American soldiers coming to him were arriving from two quarantine camps in Polish territory south of the city. They were run by two of Gilchrist's other medical officers. At these camps the men were supposed to have been bathed, deloused, isolated from new arrivals, and then dispatched to Dunbar at Danzig for the final pre-boarding procedures ${ }^{51}$.

But in practice there were all sorts of problems and after two transports had left for America another camp site was established as the final clearance centre before embarkation from Danzig. One reason was that the quarantine and delousing measures were not fool proof. The first two ships, the Antigone and the Pocahantes, sailed without risk free assurances, and indeed two typhus cases developed en route to the United States. When the Pocahantes arrived in New York, her crew and passengers were placed in quarantine for eleven days ${ }^{52}$. For another, the arrangements ran foul of the conflicting micro-jurisdictions then governing Danzig and its hinterland. During one major transfer of Haller's men into the city, Dunbar had failed to obtain barrack space from the British authorities then running municipal affairs in Danzig. Troops on the Thorn line were held up for many hours; so long in fact that on their train food was running out

38-60; Nancy Gentile Ford, "'Mindful of the Traditions of His Race": Dual Identity and Foreign-Born Soldiers in the First World War American Army', in Journal of Ethnic Studies, 16 (Winter 1997), pp. 36-57.

${ }^{47}$ Cornebise, p. 153, nl 1.

48 ibid., pp. 113-119, 136.

49 ibid., pp. 103-104.

50 ibid.,p. 106.

51 ibid, pp. 105-106.

52 John H. Linson to Rupert Blue, 29 May 1920, Correspondence of the Assistant Surgeon of the Public Health Service of Danzig, Poland, 1920-1921, Reel 1, Records of the Public Health Service, Record Group 90, National Archives (hereafter Reel 1). 
while Polish and British officials worked out the details which would be least offensive to the tense German Danzig population suspicious of any Polish troop movement through their city ${ }^{53}$.

Within a month after his arrival in Danzig, Gilchrist ordered Dunbar and his men to shut down the Troyl operation. He sent them about 100 kilometres south of the port city to a new site, Camp Gruppe, near the main railway line between Danzig and Warsaw which was of such concern to post World War I belligerents, and also to Jews seeking to leave Poland. For the time being Gruppe was "most congenial" to the professionals persuaded by the quarantine mentality. Geographically it was comparable to Wikoff. It was in a pine forest isolated from population centres yet connected via a camp siding to a reliable rail system. It was superior to Montauk. As a former German artillery site it had the required housing facilities. In addition, this quarantine camp had one command structure. It was in the hands of a military emergency response team dedicated to keeping typhus out of the United States ${ }^{54}$.

Indeed, it was ideally suited for experimenting with the American quarantine mentality in action, especially after some deficiency in supplies, equipment and staffing were overcome. Haller's men would come in from the initial staging camps, placed into Gruppe's "dirty camp" and then, following inspection, bathing, and delousing, isolated in the "clean" camp. At its peak of efficiency, in response to sailing schedules out of Danzig, Dunbar could delouse more than a thousand soldiers each day ${ }^{55}$.

Military discipline reinforced quarantine procedures. The troops were marched in and commanded to pay strict obedience to the rules. Violators were pulled out of the company sailing for home; they were left free to remain in Poland, but unless they complied with standing quarantine orders, they would remain ineligible for government transport. Within that framework troops had to follow the routine, from the first hair inspection, to check if each man had been properly clipped and shaved, to their last camp inspection, to check for nits and lice. Dunbar commanded and Polish-American soldiers obeyed: into the delouser, stripped with clothing into a steriliser; into a bath with strong soap; into a clean bathrobe and to a doctor: he checked for infectious diseases, lice and nits on "scalp, axillary, pubic, and anal region". Cleared, each soldier was then marked with an indelible stamp and sent with fresh socks and underwear to join his company which, as a unit, marched into a clean barrack ${ }^{56}$. In the next few days there were more general inspections, more baths and specific inspection for lice and nits; and early on the morning of their departure for embarkation at Danzig the soldiers heading for home returned to the delouser for their final bath and inspection ${ }^{57}$.

Strict rules also governed the rail journey to the Baltic harbour. Within forty-eight hours of departure on a camp siding boxcars were prepared: swept out, scrubbed, dried, and then sprayed with a five per cent creol solution. Twenty-four hours later the waiting train and its boxcars were ready for the soldiers who had been cleared, stamped with "Deloused, Camp Gruppe" on their left forearm, and segregated in a special section of the camp. En route to Danzig, United States quarantine officers and a small detachment of enlisted men maintained the isolation from the general population. By late July some 11,000 "clean" Polish-American soldiers had sailed for home ${ }^{58}$.

\section{Section VII.}

\footnotetext{
53 Cornebise, p. 105.

54 ibid.,p. 106.

55 ibid.,p. 110.

56 ibid., pp. 107-108. Each man was issued special soap with which to wash his dirty clothing and uniform.

57 Ibid., p.108

58 Some 8,000 sailed from Gruppe. Almost 3,000 had sailed before Gruppe had been set up. The departure of about 1,000 men was delayed because of fear that Bolshevik troops would sever the Warsaw-Danzig rail line, ibid., pp. 109-111. See also Linson to Blue, 29 May and 28 July 1920, Reel 1.
} 
Reminiscent of the difference between Camp Wikoff and the earlier treatment of Jews in New York City, their processing now was also different than it was for Polish- Americans at Camp Gruppe. In the wake of World War I - typhus - the cooties and nits to the American Public Health Service, had become the epidemic threatening from Eastern Europe. Between 1919 and 1921, fuelled by the forged "Protocols of Zion" and the immigration restriction campaigns in the United States, fear of Jews and typhus once again combined with special potency, indeed now with greater clarity: potentially, Jews carried the identifiable bacterium invariably found in the faeces of lice ${ }^{59}$.

Migrating Jews had also focused on Danzig, for until Riga was opened to commercial transport it was the nearest available oceanic harbour from which they could emigrate. Its strategic location in the months when the Allies blockaded German ports was coming to an end. During most of the period from late 1919 to May of 1921, Danzig, previously controlled by the defeated Central Powers, was the only former German port open to civilian shipping on the Baltic and on the North Sea. Until November 9,1920 it was under Allied control; then it turned into a Free City under the emerging authority of the League of Nations.

In other words, the way out to America was through a city and across boundaries supercharged with metaphors derived from competing nationalisms and revolutionary zeal, intense antisemitism, and the biological determinism from pre-war years. Danzig's hinterland was surrounded by the new controversial Polish Corridor and by a strip of territory that in a plebiscite in June 1920 chose overwhelmingly to remain part of East Prussia. In addition internal politics in Danzig and nearby towns was in turmoil because of competing local German and Polish revolutionary militias and the interventions in their affairs by units of the German army ${ }^{60}$.

Responses to typhus fighting efforts invariably tangled with all sorts of experiences and stereotypes, including those brought from across the ocean and those from inflamed war-time Polish xenophobic passions. Americans in Poland reported about Jews with the kind of detail and intensity usually missing from comments about ordinary Catholics in Poland. Catholics were Poles. Jews on the other hand were not identified as Jewish Poles or Polish Jews - they were seen as stereotypical figures along the lines of traditional antisemitic stereotypes.

One cool assessment of the Polish situation came from Richard P. Strong, Harvard's leader of the Red Cross typhus mission: He thought it was difficult to mount an effective campaign against the epidemic because "not enough [Poles] have died to realize it is an emergency. ... Indeed the general attitude of many of the people in Poland is hostile to anti-typhus work, perhaps," he suggested, thus echoing a widely held opinion, "because often during the German occupation the people were compelled to submit to the necessary delousing measures which were applied by the Germans with military severity ${ }^{61}$."

Gilchrist had positive impressions about Poles in charge of the anti-typhus campaign; but field reports from Paris and those coming into Warsaw told a different story. Poles were "less than helpful", "hopeless, helpless", "dilatory", "inefficient", "thieving", incapable of keeping promises, "always quarrel [ling] amongst themselves", their trains were unsanitary, and no matter what they said, they were men who did not "really know what they are doing ${ }^{62}$." From Lvov came a report reflecting the general problem: strict rules and procedures on paper but "in practice things were carried out in a perfunctory manner, largely due to the low salaries paid to the various

\footnotetext{
59 On the Protocols see Norman Cohn, Warrant for Genocide:The Myth of the Jewish World-Wide Conspiracy and the Protocols of the Elders of \%ion, New York 1967), passim. See also John Higham, Strangers in the Land: Patterns of American Nativism, New Brunswick 1955, pp. 264-311.

${ }^{60}$ F. L. Carsten, Revolution in Central Europe 1918-1919, Berkeley 1972, pp. 14-15, 271-276; Paul Robert Magocsi, Historical Atlas of East Central Europe, Seattle 1993, pp. 28,126-127,130-131.

61 . Richard P. Strong et al, Typhus fever with Particular Reference to the Serbian Epidemic, Harvard 1910, p. Richard F. Strong Papers, Box, 35-36(b-d), Rare Book Room, Harvard Medical School Library; Cornebise, p. 122.

62 ibid., pp. 35, 36, 48, 53.
} 
workers ${ }^{63}$." And in rural areas near Bedzin and Krakow doctors were often diagnosing typhus as influenza "to allay the fears of the people". Then, in violation of modern practices, they treated their patients with alcohol and coffee ${ }^{64}$.

Apparently the American typhus fighter was ignorant of Jewish practices in lifethreatening situations or he was indifferent to the kinds of experiences Jews had had during the war and were having within the new xenophobic Poland and in its eastern border lands. Pogroms by belligerents were commonplace, particularly in the Ukraine. Still, there were differences and that meant by comparison in particular instances, Soviet soldiers offered the best chance for survival. "On occasion, an entire settlement would follow retreating Red soldiers." Much of this was known at the time ${ }^{65}$.

From Tarnopol and elsewhere came reports by American typhus fighters of doctors and other Jews working with the Bolsheviks, stripping Poles of hospital equipments and supplies when the Bolsheviks retreated, and then retreating en masse towards the East ${ }^{66}$. From the town of Busko came news of Jewish distrust of medical institutions and authorities.

There] is considerable Typhus in the town [of Busko], particularly among the Jews. They are afraid to go to the hospital and use all means to keep the disease among them hidden [because they believe] that at the hospital they would not be able to live according to their religion - that they would be required to eat what the others ate - that they could never eat with their hats on and that if one of them died there he could not be buried according to his religion. This belief is being overcome and the hospital now has ten Jews as patients.

America "anyone who hid or attempted to his case of typhus". All to no avail: "it did not prove very effective as the Jews, who were afraid of the hospital, bribed the police and kept their sick hidden ${ }^{67}$."

Perhaps the most revealing document came from Robert C. Snidow, a coastal artillery officer turned by Gilchrist into a typhus fighter who was insensitive to differences in lifestyle among the inhabitants, to extreme poverty, and to religious rules governing diet and ritual bathing. The report came from June 1920, when, as a test for operational planning, Gilchrist decided to send some of his men into a town which Polish authorities had identified as the "dirtiest" one in Poland. They chose the 7000 residents of Garwolin, 70\% of whom were Jewish.

In some of the small houses of from two to three rooms, as many as fifty people sometimes lived, cooking, eating, and sleeping as well as carrying on their industries in the same small room. Typically ... the furniture would consist of a dirty table, one or two chairs, THE pot, spoons, THE washbowls, a couple of beds in the corners - during the daytime piled high with pillow and bedding which served for distribution over the floors at dusk, and the great flat tiled stove which served to heat and cook potatoes and water during the day and at night formed the base for the bedding and pillows of the patriarch and his wife who slept on the honored and warmest spot. One family or patriachate, was observed who served the repasts in [sic] the little brother of the conventional triangular

\footnotetext{
63 ibid.,p. 115.

64 ibid.,p. 117.

65 In the very months when field reports were being filed by Gilchrist's people, there were special investigations and regular press reports about all kinds of civilian attacks against Jews: in new Poland's alleys, streets, and courtyards of towns; on railways running amongst them; about military pogroms in the places being contested by armies and roving bands. See for example the pages of the English Jewish Chronicle, the New York Forward, the New York Times for 1920, and Peter Kenez, Civil War in South Russia, 19191920, Berkeley 1977, pp. 166-177.

66 This perceived conduct by Jews, reported the sympathetic historian of the American typhus fighters "accounts, at least in part, for the American dislike of Polish Jews". Cornebise, Typhus and Doughboys, pp. 116-117.

67 ibid., p. 117.
} 
pig trough of America pouring the potatoes and water into the trough after which the common spoon the tribe took turns in helping themselves to a great mouthful retiring to the outskirts to chew and swallow it. [...] In almost all of the house areas would be found after much search an open latrine which they jealously guarded from us by all kinds of disguises and camouflage as the product therefrom would be used after the harvest to put on their small patches in the outskirts of town. Most of the drinking water was obtained from a sluggish creek at the edge of the town, which a mill dam rendered more sluggish and sometimes covered the yards of some of the houses, turning them into reeking swamps." Bathing habits were atrocious: " In the first preliminary council we were assured by the priest, the rabbi and mayor and later confirmed by two doctors that not a soul in to town had had a bath for over a year. This statement we considered conservative and I personally doubt if water had touched the persons of most of them since the departure of the Germans during whose occupation they were required to bathe at least once a week, when they could be caught ${ }^{68}$.

Quarantine procedures for the Jews coming through Danzig were affected not only by passions and policies being generated in Poland; American officials, themselves informed about Jews in Poland by information reported by Gilchrist and his men, were also in webs of information coming from Germany and the United States. At a time when their government placed all sorts of obstacles in the way of Polish Jews eager to cross the border, Danzig's American officials read German claims and reports. These included the charge that Polish medical information regarding typhus and its control was unreliable, and that Jewish migrants from Poland and neighboring states occasionally brought "small pox" across the border ${ }^{69}$.

On the face of it these claims and counter claim were all about the relative medical and scientific reliability of the German and Polish public health establishments. In fact, it was also a difference driven by legacies from the past of a united Germany: chauvinism, antisemitism, and restrictionist migration policies intersecting with public health policies of neo-Lamarckian orientated biomedical cultures. All had been intensified by the war and the upheavals in its wake: Poles were primitive; incoming Jews were carriers of cholera or typhus ${ }^{70}$.

Albeit in an unusual set of circumstances, Jews themselves revealed the hold of these kinds of convictions. Jews in Poland had constituted a problem not only for German authorities but, as was well known at the time, also for many German Jews who had reasons of their own for keeping the Polish Jew out of Germany: he was no longer like them, not Western, but primitive, a threat to their place in a Germany in convulsion.

The Jewish migrants had often included war-time "guest" workers who at war's end had been sent back to Poland. Now they wished to return, often to rejoin the family they had been forced to leave behind. German authorities insisted this return flow across the war-torn eastern frontier had to be stopped in order to protect the general public from typhus, cholera, and even small pox. To some Jewish observers, however, the rational appeared tainted coming as it did in the midst of defeat, revolutionary turmoil, and a high tide of antisemitism, perhaps at a post-war peak between 1919 and $1921^{71}$. Leading politically active German Jews, including Albert Einstein and others sympathetic to Zionism and other forms of Jewish peoplehood, opposed any kind of anti-Jewish discrimination by a German government. Besides, went one of their

\footnotetext{
68 ibid., pp. 121-122, and 174, n.17, with its reference of reports from Snidow to Gilchrist, Warsaw, circa October 1920. No doubt some of the tone of this report was determined by efforts to make the claimed clean-up achievements of the unit look good. Snidow had been demoted from captain to First Lieutenant, ibid., p. 119.

69 See for example Linson to Blue, 15 November 1920, Reel 1.

70 The 1918 flu pandemic, which indiscriminately killed millions in Europe and America, seems not to have influenced public officials and their profiles in the web of information in which Danzig found itself.

${ }^{71}$ Werner Jochmann, Gesellschajlshise unci Judenfeindschafl in Deutschland 1870-1945, Hamburg 1991, pp. 99-170. See also the column 'Foreign and Domestic News' in the Jewish Chronicle for 1920.
} 
arguments, a majority of the Jews from Poland wanting to come into Germany were of "deutscher Abstammung", that is of German extraction ${ }^{72}$.

Another German-Jewish argument focused their campaign on typhus. The Jewish critics knew what the quarantine officials at Gruppe knew: typhus could be contained, managed, and stripped of its virulence before the migrants would be allowed to mingle with Germany's residents. But at that point a group of German-Jewish physicians who were Zionists, and involved with this campaign, argued against such a public health effort. Colleagues among German physicians, including German-Jewish ones, could not be trusted to be scientifically honest when it came to making diagnoses about an incoming Jew from Poland; they would abuse public health arguments to keep those Jews out of Germany ${ }^{73}$.

Quarantine officials in Danzig received constant bulletins from their superiors in Washington then being bombarded by a veritable "nordomania" media blitz ${ }^{74}$. Their attitudes usually resonated positively with those among Americans in Warsaw screening the flow of Jewish immigrants from Warsaw. This was especially the case between July and December when over 20,000 Jews, about $90 \%$ of all the emigrants then traveling from Warsaw went into and through Danzig ${ }^{75}$. They had come as railway passengers, crossing the fluid national and city borders protected by suspicious guardians, observing or engaged in the war between Poland and Russia over future state boundaries. These guards were no less hostile than the capricious and officious Polish and American clerkdoms in Warsaw that had reluctantly approved the Jews' departure in the first place; some, like John C. White, American charge d'affairs in the Polish capital, tried unsuccessfully to prevent American-Jewish organisations, such as the Hebrew Immigrant Aid and Sheltering Society (HIAS) from aiding Jewish immigrants in transit. On July 9, 1920 he put the point in classic diplomatic language: "In as much as practically all of the immigrants who pass through Danzig are of decidedly inferior types physically, mentally and morally and, because their insanitary habits, constitute a menace to the health of all with whom they come in contact, it is my opinion that efforts to stimulate their emigration to the United States should be discouraged ${ }^{76}$."

These sort of expressions were part of the contentious discourse in the corridors of the Department of State and in the halls of Congress during the hearings about the legislation designed to stop the very Jewish migrants trying to board ship in Danzig. In the spring and summer of 1920, at the height of the typhus epidemic and military crisis in Poland, consular survey reports had been sent to Washington about potential European migrants. In the fall and winter, the leadership in the House of Representatives, fighting for the new law in Senate hearings requested summaries of those reports and presented them to the senators. In the summaries Jews from Poland, whether in the new Poland or in its neighbouring countries and their Atlantic ports, received special attention by virtue of the dangerous attributes ascribed to them. They were the only group repeatedly identified with contagious diseases as well as threatening social, political, and economic characteristics.

\footnotetext{
72 Einstein published his defense of the migration of "Ostjuden" in the Berliner Tageblatt. Jiidisclie Rundschau, 6 January 1920.

73 Evidence for this interplay of Jewish workers, antisemitism, public health positions, Zionists and German border policies is in files F4/28 and Z3/ 202, 203 in the Central Zionist Archives in Jerusalem and in Trude Maurer, 'Medizinalpolizei und Antisemitismus: Die deutsche Politik der Grenzsperre gegen Ostjuden im Ersten Weltkrieg', in Jahresbiicher JUr Geschichte Osteuropas, 33 (1985), pp. 205-229, where she cited these and related files. See also idem, Ostjuden in Deutschland, 1918-1933 , Hamburg 1986, pp. 57, 258.

${ }^{74}$ Henry L. Feingold, A Time for Searching: Entering the Main Stream 1920-1945, Baltimore 1992, pp. 1-28. I thank him for the expression "nordomania".

75 Between October 1920 and 1 January 1921, Linson sent Rupert Blue, his superior, weekly reports of emigrants going through Danzig's migration camp. The quarantine men at Danzig visited Gruppe and typhus control stations in Warsaw. J. H. Linson to Blue, 10 May 1920, Reel 1.

${ }^{76}$ Liason to Surgeon J. W. Kerr, 9 July 1920, Reel 1. As described below, White was denouncing the work of HIAS ,in Danzig's Troyl Camp, accusing it of spending on a large scale to help Jewish immigrants to the United States by advancing money to those who could not pay for passage. See also the more nuanced claims of U.S. Immigration Commissioner Anthony Caminetti. United States Senate, Hearings of the Emergency Committee on Immigration, 1921, Microfiche copy, pp. 574—577.
} 
The timing of this presentation, at the end of 1920, was significant. Albeit not a demonstrable fact at the time, the presentation occurred after the typhus epidemic in Poland had started to ebb. It had climbed from 1916 to a peak in mid-1920, and dropped just as sharply as it had spiked a few years earlier when Germany had occupied the country ${ }^{77}$. Here, from the spring of 1920, are summaries from Warsaw about emigrants expecting to travel to the United States. (There were similar ones from Romania, Austria, Germany, the Netherlands, and one from France about a form of cholera.)

[The emigrants are] physically deficient, wasted by disease and lack of food supplies ... mentally deficient ... socially undesirable. ... Eighty five to ninety percent lack any conception of patriotism or national spirit and the majority of this percentage is mentally incapable of acquiring it. ... At the moment 90 per cent may be regarded as a low estimate of the proportion representing the Jewish race among emigrants to America from Poland. The unassimilability of these classes politically, is a fact too often proved in the past to bear any argument. ... Many of these persons have ... quarantinable diseases and come from typhus infected areas. They are filthy and ignorant and the majority are verminous. Persons who come into contact with these prospective emigrants [in any European port] are obliged owing to their unsanitary conditions, to take the greatest precaution to avoid contamination. ... Some emigrants are objecting to "certain sanitary provisions such as removal of beards and clipping of hair.

The summer reports were similar. "Reports indicate 34,538 cases of typhus in Galicia and Poland in 1916, 43,485 in 1917, 97,082 in 1918, and 232,206 in 1919, and the first two month of 1920, 16,500. Typhus situation in Poland shows little improvement despite active campaign against it. Refugees from infected region in Russia are constantly pouring into Poland. ... All emigrants who pass through Danzig are decidedly inferior type, physically, mentally, and because of their sanitary habits constitute a menace to the health of all with whom they come into contact. ... Crowds collecting in Warsaw for the purpose of procuring necessary papers to enable them to emigrate are alleged to be a menace to the health of Warsaw." A report from early fall sent a message about the coming dangerous tidal wave: It was alleged some 350,000 "Polish subjects of the Hebrew race" wanted to go to America - in the next three years five million of them. "It is impossible to overestimate the peril of the class of emigrants coming from this part of the world, every possible care and safeguard should be used to keep out the undesirables ${ }^{78}$."

\section{Section VIII.}

There were important differences between practices involving the returning PolishAmerican soldiers and Jewish immigrants. As in the case of Wikoff, at Gruppe, too, the governing assumption controlling quarantine procedures was one of 'can do', with time, discipline, adequate staff and support, and with the cooperation of the troops and their commanders. In neither camp was there any doubt that typhus was containable and that, with quarantine, it was a contagion that could be stripped of its virulence. To be sure, Wikoff had all sorts of serious problems with its quarantine practices on the camp side of the shore line, and at Gruppe too there were lapses. But among the enforcing public health authorities there was no doubt that the population of the American republic was secure in its hands. When there was needless suffering among the troops, or gaps in the quarantine screens, critics pointed to the army's logistical incompetence or the incompetence of some of its officers in Washington or in

\footnotetext{
77 Sidney Brooks, 'America and Poland 1915-1925', in American Relief Bulletin, Series 2, No.44 (Aprill925), page between pp. $48-49$ for the graph 'Spread and Conquest of Typhus in Poland'.

${ }^{78}$ Emergency Committee on Immigration, 1921, pp. 8-21.
} 
the field. During the time of Wikoff, typhus-infected soldiers were not held responsible for collapsing in railway stations of the Long Island Railroad or on of the sidewalks of Manhattan; it was the army physicians at Wikoff who had not acted in line with public health knowledge about how best to control and contain the contagious disease. During Gruppe, the troops were PolishAmericans, whose kinfolk in the United States were subjected to all sorts of discriminations, especially in media campaigns by steel magnates struggling with post-war labour unrest - Poles in the work force, they proclaimed, were fodder for radicals organising strikes. Indeed, an American military intelligence report about these returning soldiers from Haller's army said they "are not on the whole, a desirable element. Most of them have come from the large manufacturing [centres] such as Chicago, Buffalo, Pittsburgh, and are what we would consider in our own army a rough crowd $^{79}$." When they filed past quarantine inspectors, it was obvious, that there was something about the soldier's tunic and his American military service papers that served him well: both intersected to his benefit with medical information obtained from him in terms of the germ theory of disease. And more. The commander at Gruppe not only welcomed the Red Cross and YMCA, HIAS-like voluntary organisations, to help the army provide for soldiers' personal needs. He also instituted special dental programmes to assure the best of health for his Polish-American charges when they returned to civilian life in their home towns ${ }^{80}$.

Public authority in Danzig treated migrating Jews quite differently ${ }^{81}$. To begin with, Poland did not cloak the migrants with the protective shield of citizenship. Jews had little if any recourse to any government when harassed or exploited. It was a radicalisation of normal conditions experienced by most people engaged in longdistance migration across foreign borders, especially at the places where they actually crossed national frontiers. Within the turmoil brought on by war and revolution, the formation of news states, and what some at times called "permanent pogroms," hazards of travel and currency exchange threatened to strip Jews of their belongings, their beards and side locks, and often left them all but penniless by the time they arrived at the Baltic Port.

For the exit through Danzig now involved new American procedures at designated US consulates or embassies and at ports of embarkation. In comparison to prewar days, migrating civilians needed a visa stamped into their passport and required the twelve day quarantine which had become mandatory at Gruppe early on. Both requirements caused days of delay far from home, well beyond the control of the migrants. Indeed, the delays served as an important engine of exploitation. At the beginning of migration, when migrants had to "wait for steamers" the lodgings available to migrating Jews were in the hands of Danzig's German landlords; and they charged unregulated rents by the day ${ }^{82}$.

In the late spring of 1920, Troyl, the very place that Gilchrist had ordered evacuated a few weeks earlier, became the site of the transit camp for Jewish migrants coming in from Warsaw. They and the various Americans who screened or worked with the immigrants had to somehow manage with the same public authorities from whose authority Gilchrist had removed himself. In practice this meant that American consular officials, public health physicians, and representatives of private organisations, such as the Hebrew Immigrant Aid Sheltering Society

\footnotetext{
79 Quoted in Cornebise, p. 101.

80 ibid. This dental work was probably part of the larger effort made by the U.S. Army to provide social uplift and Americanisation exposure for immigrant soldiers. Ford, pp. 40-42. For a larger context of this work see Gerd Korman, Industrialization, Immigrants, and Americanizers: the View from Milwaukee, Madison 1967, pp. 65-202.

${ }^{81}$ For responses among Jews in Danzig to the migration crisis see the following in the Central Archives for the History of the Jewish People, Hebrew University (hereafterCAHJP): Eliyahu Stern, "The History of the Jews in Danzig. 1840-1943", PhD Dissertation, Hebrew University 1978; Dr. J. Kurt Nawratzki,"Yiddische Auswanderung uber Danzig", Typescript Report, nd; Nawratzky to Zionistisches Zentral Bureau in London, 17 August 1920; Summary Notes: Danzig Comitee fur Wanderarmenfursorge, 11 April 1920 , Danzig Jewish Immigration Committee, 15 April 1920.

82 Frances Kellor, Emergency Committee on Immigration, 1921, pp. 422-429; Report of the European Commission of HIAS, Typescript, 11 August 1920, HIAS Archives, Institute for Jewish Research [YIVOl; (hereafter HIAS).
} 
had to improvise on an ad hoc basis and negotiate with competing local authorities, steamship and railway organisations, manufacturers and suppliers of delousing equipment.

Sooner or later, quarantine drove everybody's agenda because the isolation required each migrant to stay in one guarded place for twelve days. Once HIAS became engaged, it focused on the same jugular issues as had the military, transportation and housing officials, but first, in the Polish capital, together with the Joint Distribution Committee, it tried to break the passport and visa bottlenecks which were rife with antisemitism, graft, and corruption. ("The question of Polish clerks who don't like Jews and mistreat our people terribly is one continuous problem.") In Warsaw HIAS representatives met the American consul whose "very small quarters," could not possibly "handle with any degree of expedition the large and ever increasing number of application for visas." When the consul informed them he was negotiating a lease for a bigger office, they were also told that the landlord demanded \% 10,000, a rent advance of three years, before signing a lease with the consul. The problem was that the Department of State had approved the lease but had funds for only the first year; and efforts to obtain a loan from a local banker had proved futile. So the consul "applied to us for a loan of $\$ 5200$ upon which he was willing to pay interest. We, of course, advanced the money without any interest at all. We felt it a privilege to be of assistance to our government in so great an emergency." Still, six or eight weeks "elapsed before passports were issued to immigrants, sometimes only after heart wrenching decisions splitting migrating families. ... We found that fully 90 per cent of the [newly required affidavits of support] which had been sent from America were lost in the mail never reaching the addressees." In Rotterdam and Antwerp the bottlenecks were worse ${ }^{83}$.

HIAS was more successful in solving problems of transport and lodging. Its representatives managed to obtain from the Polish government special immigrant trains running from Warsaw to Danzig, a twelve hour journey fraught with all sorts of problems but much shorter and safer than two weeks of "misery" to ports in Western Europe, where at journey's end the immigrants, with their Yiddish, Polish, and German, arrived in places where they did not know the language. In the absence of constant, direct civilian passenger traffic between the Baltic port and the United States, HIAS arranged with the Cunard and White Star steamship companies to run "small steamers to English ports where they would be transferred to the big liners going to America"; a similar arrangement would send immigrants to the United States via Le Havre ${ }^{84}$. Both options raised all sorts of complaints, against HIAS and about effective American quarantine control during these migration transfers from one European port to another.

In the absence of the kind of military arrangements governing the establishment of Wikoff and Gruppe, HIAS moved into the vacuum by dealing with German, English and Polish public authorities regarding the use of the vacant facility that the Germans had used for prisoners during the war. No one seemed to own it. The Germans and English were each prepared to let HIAS rent it, so to speak, as long as the Poles were not involved; and the Poles for their part dealt with HIAS on those terms. "Everybody claimed to be the owners of the camp. Finally we came to an understanding with the [Polish] authorities of Danzig by which we could use the camp for Jewish immigrants." Poles "were to manage the camp whilst we were to regulate prices. It was agreed that the immigrants should be charged 16 marks for a night's lodging which included ... transporting baggage from the railroad station to the camp and from the camp to the steamer. Food, including any medicine that may be necessary was charged at the rate of 22 marks a day per person ${ }^{85}$." In addition to these charges, the Polish Commission of Danzig, charged for the city

\footnotetext{
83 Report of the European Commission, pp. 15-17, HIAS.

84 ibid., pp. 21-22.

85 ibid., pp. 22-23. High prices, complex negotiatons with city officials and the camp director, and the delays from quarantine imposed all sorts of burdens on Danzig's Jewish organisations. Dr. [Rabbi] Kelter, Comitee fur Wanderarmenfiirsorge, 11 April and 12 June 1920, GAHJP; Denkschrift des jiidischen Comitees, 11 October 1920.
} 
a fixed fee of 20 marks for delousing. These fees were "to be paid by each immigrant," that is by HIAS in the event the immigrants could not afford to pay the fees ${ }^{86}$.

These arrangements occurred in the shadow cast by quarantine officials of the American Public Health Service who in the face of the typhus epidemic went into an emergency mode. On 20 May 1920, Hugh Smith Cumming, its Surgeon General, notified Assistant Surgeon General Rupert Blue, in Paris, that John H. Linson, who had recently been transferred from Marseilles to Danzig,

and others like him are to delouse emigrants and supervise fumigation of vessels. ... Until there has been a material decline in the typhus rate in Central Europe, I think that all emigrants from European ports should prior to embarkation, be thoroughly deloused, and that steamship companies at the respective ports should provide adequate facilities in the way of barracks, bath houses, etc. to accomplish this purpose.

Cumming would send these types of warnings throughout the year ${ }^{87}$. A few days later Linson himself went to Warsaw to discuss the typhus situation with Gilchrist, who had just returned from a general inspection tour. He told him that practically no delousing was being done: there were shortages of coal, no food for patients, sterilisers were rusting, hospitals were practically empty. Linson told Blue that medical officers were urging that removal of hair, "especially the whiskers, is an essential part of the delousing process ${ }^{88}$." For the Jewish immigrants this part of the delousing procedure was symbolically threatening and rife with indecent conduct. Militant "Westernized" Jews in Europe and America had long mocked beards and side locks; and in these weeks of pogroms and random hooliganism, physical attacks on Jews often included ripping out or cutting those facial hairs. There were repeated reports of women being photographed while taking delousing baths. But, of course, the formal quarantine procedure was onerous enough; indeed, HIAS officials, who compared "scientific requirements" in the quarantine procedures at Ellis Island thought Danzig's requirements were "cruel. They are not civilized." In Danzig the "American doctor has charge of it. He is very strict. He will not give a certificate to any man or women who has lice or who is affected by anything. In the examination he says cut off your hair or you cannot go." Women acquiesced, reported a HIAS observer, "rather than go back to their home. They agree to cut their hair. The hair on the body was to be removed by a certain lime to boil off the hair. Many persons did not know how to stand while the lime was on. If the lime gets wet it burns the skin." After September 4, women or religious men who objected to shaving apparentiy could opt for a treatment using a mixture of "equal parts kerosene and vinegar for at least one hour ${ }^{89}$."

At the time, in the tense days of summer, the immigrants and HIAS related to quarantine in much the same spirit that merchants, concerned about their quarantined cargoes, had historically related to it. If they could not get rid of it entirely, they tried to reduce the length of the isolation, if only because each day locked up was one more day of expense and of all sorts of losses from collateral damage ${ }^{90}$. "There is a great deal of bitterness among the people while in quarantine. When the people have to stay in quarantine for 12 days they want to go to the city. When they come back they are told that those five days you were away do not count at all. They

\footnotetext{
86 ibid., pp. 22-23.

${ }^{87}$ H. S. Cumming to Blue, 20 May 1920, Reel 1. See also ibid., 13 October 1920 and Public Health circulars; one was concerned with bubonic plague in Mediterranean ports.

${ }^{88}$ Linson to Blue, lOMay 1920, Reel 1.

89 Report of the European Commission 1, HIAS; A. Surgeon to Blue, 4 September 1920, Reel 1.

${ }^{90}$ On merchants and cargoes see for example, Evans, pp. 372-379. In 1917 Cofer wrote Booth \& Co., Inc., steamship agents of New York, that the "use of cyanide gas is being perfected to a point where in the not distant future it will be possible to fumigate vessels in one-third or even one-fourth the time that was formerly required in sulphur fumigation." Cofer to Lawson, Sandford, 10 May 1917, NA/B.
} 
are kept the same as prisoners. When they come back they are told your days start from now on ${ }^{91} . "$

To complicate matters, by late summer there was American pressure to shut down the Troyl camp. All sorts of problems existed and motives were mixed. Linson did not want to continue to sponsor a delousing establishment "in which sanitation, personal comfort and humane treatment are ignored"; for such conditions where both sexes "crowded together in dirty and uncomfortable barracks ... [would] promote the spread of contagious diseases" and "immoral relations between the sexes"; and with winter coming, the "poorly clad and underfed" women and children, who at the time were the "majority of ... immigrants constituted a special problem." But Linson obviously recognised the impact of these conditions on the flow of migration: "It is not unreasonable to assume that the volume of immigration through Danzig will be gready affected by the unpleasant experience through which so many immigrants are passing ${ }^{92}$."

On August 30, the Public Health Service did temporarily withdraw its approval, thus holding up the delousing and disinfection process of 190 passengers in the camp. When it did recertify, for the sake of those immigrants, new rules were required of the city: Linson demanded and got "the assistance of ... four persons because in the past the bathing and disinfection at the Troyl camp has been notoriously inefficient": one record keeper for the clothing being processed, which now had to remain in steam sterilisers for 40 minutes at $100^{\circ} \mathrm{C}$; one man and one woman for supervising the bathing of each immigrant, who now had to stay in the shower for at least 5 minutes "using soap freely and paying special attention to hair" - this procedure included the use of acetic acid to "kill the nits" which were then removed with fine tooth combs and finger nails by friends of passengers or the woman hired to do so; and one examiner for patrolling the entire process. Linson also insisted that in future, after receiving their cleaned clothing, each immigrant go direcdy to the departing steamer ${ }^{93}$.

The tight sailing schedules of those steamers could intensify frustrations and anxieties as capricious conduct and control of departure permits by American doctors took its toll. "On the second day of July, Friday," reported a HIAS official,

I went to the ticket office of ... [a representative for the Gunard Line]. I was told tomorrow there will be a steamer going to England. The steamer will stay only two hours in Danzig. He said that if we had the immigrants that are through with the quarantine, we should have them ready and they will take them on. In order that they should be able to go, they have to get a certificate from the doctor. There was no doctor there since it was 4 oclock. I was told the doctor was in his bathing place, about forty miles away. We hired an automobile and rushed over there. We found him in a hotel playing. ... We told him the story. ... He said his business hours are over. We explained that there is a shortage of steamers and now we can take away 250 immigrants. He said he cannot do anything. For the people to remain meant that the longer they stay the more they suffer. This man did not move from his place ${ }^{94}$.

Even as the the Public Health Service continued its high alert warnings, by year's end Linson was forced to admit that his Jews had not been verminous. In a note to an inquiring fellow physician in the Service, he wrote there was no typhus fever in Danzig. "We have had only two suspected cases since the opening of the camp. In fact I must confess that I have never yet seen an

\footnotetext{
91 Report of the European Commission, 1, HIAS.

92 Linson to HIAS and Karlsberg Spiro \& Co., 2 September 1920. Memo: Ein- und Auswandererlager, Danzig, Troyl, 21 September 1920 and Linson to Doctor Haralson, 2 November 1920, Reel 1.

93 Memo: Ein- und Auswanderer Lager, Danzig, Troyl, 21 September 1920 reporting the hire of Kitty Scheffler as stenographer and assistant in checking the delousing at Troyl, and Linson to Doctor Haralson, 2 November 1920, Reel 1.

94 Report of the European Commission, 17, HIAS.
} 
authentic case of typhus fever ${ }^{95}$." In New York's quarantine station in the meanwhile the tone about the migration out of Poland was also beginning to change. To be sure, in the spring of 1921, Blue is still pressing his officers in Europe to "secure cleaner ships" and in New York and other oceanic ports officials are asked to be prepared in the case of typhus for quarantining passengers for twelve days; for it was clear to him: "Absolute control... is not possible at foreign ports ${ }^{96}$." But, in line with Linson's experience, Blue now "did not believe that any restrictions should be imposed against emigrants departing from Poland or the Baltic regions"; no cases had been reported since March $^{97}$.

No doubt the epidemic had passed its peak - the medical charts were falling back to their pre-1916 levels. Yet two other factors were now in play. The Emergency Immigration Act was scheduled to go into force at the end of the month: it would stop all mass migration out of Europe in general, out of eastern and southern Europe in particular. And bacteriologists had closed in on typhus: Arthur Felix and Edmund Weil had described a diagnosis of typhus that used the patient's blood serum $^{98}$, and within a few years the laboratory test was being used successfully for screening and confirming typhus in ways similar to diagnostic tests for cholera among passengers arriving at Atlantic ports. So on 22 June 1921 the Medical Superintendent of the Department of Health, at Canada's quarantine station at Gross Isle, in Montmagny, Quebec, could confirm, for the Medical Officer in Charge, at the United States Quarantine Station in New York, that yes indeed there was typhus fever aboard the Oristano. His station had used the Felix- Weil test to prove that "we had really to deal with cases of typhus fever. ... [It] has given us entire satisfaction ${ }^{99}$."

\section{Section IX.}

In comparison with returning troops, the quarantine treatments and experiences of migrating Jews from new Poland and old Russia had been similar but different. Both groups had shared all sorts of uncertainties brought on by the exigencies of war or post-war problems. They had also been victims of conflicting chains of command, incompetence, ignorance, capriciousness, corruption, and the snarls of bureaucracy. They had all suffered needlessly from indifference to or perhaps tolerance of human suffering by officials masking ignorance and serving under the cloak of guardianship of the republic. The obvious differences in the treatment between incoming soldiers and incoming Jews need not be restated in these concluding remarks.

Some implications of these differences deserve to be teased out. In the absence of sulfa drugs or other antibiotics, the darker sides of quarantine mentalities in America's liberal democracy had changed during a critical moment, when heredity had met the bacterium. Clearly, after WWI, the more modern and professional public health service insisted on testing when in doubt rather than on imposing quarantine. But all along, there had remained significant gaps between diagnoses and cures of threatening contagious diseases.

In the neo-Lamarckian biomedical culture of these years the gaps had been readymade for acts of biological politics. These would shield the returning soldier in the service of the republic, even as they were targeting Jews in anti-immigration campaigns and within legitimate structures of quarantine. While still believing in the inheritance of personal and collective characteristics, be they "natural," or "acquired," especially during times of emergency, in the

\footnotetext{
95 Linson to Doctor Haralson, 2 November 1920, Reel 1.

96 Blue to Cofer, 9 May 1921; J. Perry, Acting Surgeon General to Cofer, 19 May 1921; Cofer to Blue, 10 June 1921, Reel 1.

${ }^{97}$ Blue to Cofer, 9 May 1921, Reel 1.

98 Arthur Felix and Edmund Weil, 'Zur serologischen Diagnose des Fleckfiebers', in Wiener klinische Wochemchrj/l, 29 (13 January 1916), pp. 33-35.

9912 June 1921. By then J. E. Holt Harris, director of the laboratory at the New York Quarantine Station had been reporting regularly about his "Weil-Felix" reactions. L. E. Cofer to R. H.Creel, Asst. Surgeon, 17 November 1920, NA/B.
} 
name of the republic's public good, the practitioners' modern scientific eye now fixed each traveller as potentially pathogenic, that is as a potential killer. With that gaze local and federal American health authorities, at home and abroad, helped to shape anti-immigrant rhetoric that could be group specific, enforce confinements, evictions, burning of private belongings, and when fearing dogs, enforce orders to kill them with gas.

Indeed, in late nineteenth and early twentieth century, in their totality these kinds of efforts by United States officials had important consequences, some certainly unanticipated. Especially while a typhus epidemic was raging in Poland, they may well have contributed to the complex process by which quarantine-connected health officials helped to build part of the platform on which American public officials responded to a German fascist regime reconstructing the Jew as the new old mortal enemy of modern civilised society ${ }^{100}$.

100 William W. Hagen, 'Before the "Final Solution". Toward a Comparative Analysis of Political Anti-Semitism in Inter war Germany and Poland', in Journal of Modern History, 68 (June 1996), pp. 351-352; Saul Friedlander, Nazi Germany and the Jews: The Years of Persecution, New York 1997, pp. 39-40, 207-210; Charles Meier, 'Introduction', in Thomas Childers and Jane Caplan (eds.), pp. xii$\mathrm{xv}$. 